\title{
Heidegger's Underdeveloped Conception of the Undistinguishedness (Indifferenz) of Everyday Human Existence
}

\begin{abstract}
Jo-Jo Koo
(Published in in H. B. Schmid and G. Thonhauser (eds.), From Conventionalism to Social Authenticity: Heidegger's Anyone (das Man) and Contemporary Social Theory. Cham: Springer International Publishing [Studies in the Philosophy of Sociality], 2017, pp. 53-78)
\end{abstract}

\section{Introduction and Translation Choices}

Heidegger's conception of the 'one' or the 'anyone' (das Man) in Being and Time, ${ }^{1}$ along with the central but also ambivalent role that it plays in his account of the basic sociality or social constitution of the human being $\left(\right.$ Dasein $\left.^{2}\right)$, continues to generate divergent interpretations that form a lively ongoing debate. ${ }^{3}$ In light of Heidegger's mostly pejorative descriptions in that text

\footnotetext{
${ }^{1}$ All references in this chapter to Heidegger's Sein und Zeit (Heidegger 1993) will be indicated and abbreviated henceforth as SZ. Although I have occasionally consulted the English translation of this text by Macquarrie and Robinson (Heidegger 1962), as well as Schmidt's revision of Stambaugh's translation thereof (Heidegger 2010), all translated passages into English from Sein und Zeit in this chapter are my own. The German pagination is given in both English translations. All italicizations in the quotations that I translate from Sein und Zeit are Heidegger's own. Although the citation convention of non-English words typically italicizes these words in English texts, I have decided to leave unitalicized the longer passages from Sein und Zeit that I translate into English for the sake of clarity and practicality. This decision enables both Heidegger's own emphases in the original German to be clearly displayed, and also the emphases that I myself wish to add into the cited passages to stand out clearly.

${ }^{2}$ Strictly speaking, Dasein is defined as the (kind of) entity that comports itself toward all entities (Seiende), including itself and others of its kind, on the basis of an understanding of the being (Sein) of entities (SZ 12; cf. 6). Human beings and Dasein are not always coextensive, though usually they are so. Dasein is not fundamentally a (kind of) thing, object, subject, or organism, but a distinctive way of existing in and toward the world that involves the necessary embodied actualization of certain interdependent abilities, dispositions, and constitutive structures. For lucid explanations, see Carman 2003: 35-43 and Blattner 2006: 33-41.

${ }^{3}$ There has recently been a veritable explosion in the literature about the proper understanding of das Man: see, e.g., Schmid 2009; Freeman 2011; O'Brien 2011 and 2014; Richardson 2012: Ch. 4 and 5; Christensen 2012; Egan 2012; Rousse 2013; Han-Pile 2013; Blattner 2013 and 2015; Magid 2015; Stroh 2015; McManus 2015; Koo 2015 and 2016. Since its publication, Dreyfus's influential interpretation (among much else) of the positive as well as the negative functions of das Man (Dreyfus 1991: esp. Ch. 8 and 13) continues to set the main terms of debate about this topic for many interpreters of Heidegger's Being and Time especially in the English-speaking world, by serving either as an insightful interpretation worthy of sympathetic correction and defense (e.g., Carman 1994 and 2003: Ch. 3 and 6), or else as a central target of criticism (e.g., Mulhall 2013: Preface to the Second Edition; cf. McManus 2015: Introduction). Besides Dreyfus 1991, some important past literature on this topic that has continually shaped and informed the context for the contemporary literature are: Löwith 2013; Theunissen 1984; Habermas 1987 and 1992; Haugeland 1982 and 1992; Rentsch 1999 and 2000; Figal 1991: §§5, 7-8; Olafson 1987, 1994a, and 1994b;
} 
of how the anyone pervasively governs and maintains the average (durchschnittliche) way in which human beings make sense of and live their everyday lives (SZ 43, §27, 166f., §§35-38, $\S 52,297-300)$, it is understandable why many interpreters of Being and Time associate everyday human existence with living life under the sway of the anyone, rather than existing and acting in ways that actualize human beings' ability to come to 'own' themselves (see esp. $S Z \S \S 27,38$, 62). For this reason Heidegger describes this specific mode of human existence as uneigentlich, which is often translated into English (and other non-Germanic languages) as 'inauthentic' (Heidegger 1962: 68 and passim). Conversely, many interpreters associate the other specific mode of human existence that succeeds in challenging the legitimacy of the anyone with the mode that is eigentlich, a way of human existing in which certain human beings come to 'own' their existence by responding 'resolutely' (entschlossen) in the face of certain extraordinary situations in their lives; on this view, it is this distinctive eigentliche mode of comportment that opens up the possibility of achieving 'authenticity’ ( $S Z \S \S 46-64)$. This general interpretive orientation holds that there are only two specific modes of human existence that are supposedly mutually exclusive: 'authenticity' (Eigentlichkeit) and 'inauthenticity' (Uneigentlichkeit). As Heidegger writes:

The self of everyday Dasein is the anyone-self [Man-selbst], which we distinguish from the owned $^{4}$ self, i.e., the self that seizes itself as its own [das wir von dem eigentlichen, das heißt eigens ergriffenen Selbst unterscheiden]. ... Initially [Zunächst ${ }^{5}$ factical Dasein is in the common world [Mitwelt] that is uncovered in an average way. Initially it is not 'I' who 'am' in the sense of the owned self, but others in the way of the anyone. From the

Dreyfus 1995; Schatzki 1992 and 2005; Blattner 1999 and 2006; Carman 1994, 2003, 2005; Keller and Weberman 1998; Holland and Huntington 2001: Part I; and Boedeker 2001.

${ }^{4}$ I will explain in due course why 'owned' is preferable to 'authentic', and 'unowned' to 'inauthentic', as the better English translations of these terms.

${ }^{5}$ Dreyfus, Haugeland, and Blattner propose that Heidegger's use of 'zunächst' be translated as 'primarily' in English (Dreyfus 1991: xii). While there is very good hermeneutic sense in doing so, I have chosen to translate it as 'initially' in order to bring this translation closer to its colloquial use in German. That said, it is, indeed, informative to understand Heidegger's use of 'zunächst' as also expressing 'primarily', especially in his frequent use of the expression 'zunächst und zumeist' ('initially/primarily and mostly') throughout Being and Time. In what follows the reader should thus also hear 'primarily' whenever I use 'initially' in this chapter. 
anyone and as this, [my] 'self' is initially 'given' to me. Initially Dasein is the anyone and mostly [zumeist] remains so. ... Everyday Dasein draws the preontological interpretation of its being from the mode of being of the anyone, which is most familiar [nächsten] to it. (SZ 129f.)

Given that human beings in their everyday lives exist initially and mostly (zunächst und zumeist [cf. SZ 370]) as the anyone-self, it seems, then, that almost all of us, barring extraordinary circumstances, live 'inauthentic' lives in light of this prevalent existentialist interpretive orientation.

Careful interpreters of Being and Time have noticed, however, that there is textual evidence that Heidegger actually conceives of a third specific mode of human existence that is distinct from both Uneigentlickeit and Eigentlichkeit. ${ }^{6}$ If so, its distinctiveness would create the phenomenological and conceptual space for seeing how there can be a specific mode of existence for human beings that is not 'inauthentic' in a simplistic way. He calls this mode the Indifferenz der Alltäglichkeit:

At the outset of the analysis, Dasein should precisely not be interpreted in [terms of] the difference of a determinate existing, but revealed in its undistinguished initially and mostly [in seinem indifferenten Zunächst und Zumeist]. This undistinguishedness ${ }^{7}$ of everydayness [Indifferenz der Alltäglichkeit] is not nothing, but a positive phenomenal character of this entity. All existing, as it is, comes from out of this mode of being and back into it. We call this everyday undistinguishedness of Dasein averageness. (SZ 43, first two emphases added)

Mineness in each case [Jemeinigkeit] belongs to existing Dasein as the condition of possibility of ownedness and unownedness. Dasein exists in each case in one of these

\footnotetext{
${ }^{6}$ I will provide and interpret this textual evidence below. Dostal (1982) is the first to my knowledge that extensively examines Indifferenz as a third mode of human existence that is distinct from Uneigentlichkeit and Eigentlichkeit, though he writes in his article that it was Marjorie Grene who first brought it to his attention (1982: 43n1). Dostal also mentions his access to Dreyfus's then still unpublished interpretation of Being and Time as another impetus for his reflections on Indifferenz as a distinctive mode of human existence (1982: 50n8; cf. eventually Dreyfus 1991: 27, 194, 235). Most interpreters of Being and Time do not note or else do much with this third mode of human existence. Some notable exceptions are Blattner 1999, 2006, 2013, 2015; Carman 2000 and 2005; Han-Pile 2013; Wiesnewski 2013: 32f., 129f.; and Magid 2015.

${ }^{7}$ I will explain shortly why it is better to translate 'Indifferenz' into English as 'undistinguishedness'.
} 
modes, or in their modal undistinguishedness. [Dasein existiert je in einem dieser Modi, bzw. in der modalen Indifferenz ihrer.] (SZ 53, emphasis added $)^{8}$

What is the undistinguishedness of everydayness? What is its textual and philosophical significance in connection to that of the anyone? What potential can it have (if any) for social theory and social criticism? My central aim in this paper is to show how the undistinguishedness of everydayness, which admittedly Heidegger seriously underdevelops as an explicit topic of analysis in Being and Time, ought to play a much more prominent role in how we should understand everyday human existence in connection with the anyone and human sociality more generally.

Some brief remarks are necessary about the appropriateness of the translation choices of three key terms that figure centrally in this chapter. These choices about their proper translation are neither linguistically nor philosophically trivial. The terms in question are: Eigentlichkeit, Uneigentlichkeit, and Indifferenz. Contrary to the usual translation of the first two terms, respectively, as 'authenticity' and 'inauthenticity', it is much better, for reasons given in the next section, to translate Eigentlichkeit as 'self-ownership' or 'ownedness' and eigentlich as 'owned' (with the prefix 'self-' elided), and correspondingly Uneigentlichkeit and its cognates as 'unownedness' or 'unowned'. The choice of translating Eigentlichkeit and its cognates as 'selfownership' or 'ownedness', and in particular Uneigentlichkeit as 'unownedness' and its cognates, will also have philosophical significance below. Furthermore, it is more informative to translate Indifferenz and its cognates into English as 'undistinguishedness' rather than 'undifferentiatedness' (Heidegger 1962: 69 and passim) or, unhelpfully, 'indifference' (Heidegger 2010: 43 and passim). 'Undistinguishedness' is preferable for two initial reasons

\footnotetext{
${ }^{8}$ Magid's interpretation of Indifferenz notices and interprets how we should understand this use of ' $b z w$.' (beziehungsweise) in the original German (Magid 2015: 12-14). It will emerge that his interpretation and mine are in opposition. I will address his interpretation toward the end of section 4 below.
} 
(others will be given and justified below). First, existing in an undistinguished way obviously does not mean existing in an indeterminate or undefined (unbestimmte) way. Living in an undistinguished way involves one's thoroughgoing immersion in the common richness and complexities of everyday human life, so this way of living human life is actually very differentiated in myriad ways. 'Undifferentiatedness' has the drawback of implying indeterminateness or lack of definition: of lacking relatively defined social roles, expectations, tasks, emotions, activities, and, more generally, socioculturally specific ways of being selves. But this lack of concrete determinateness fails precisely to capture what Heidegger means by Indifferenz (e.g., SZ 126f., 192), which highlights the concrete experience of such determinateness in everyday life and yet still discerns it as impersonal and public with regard to the degree to which it enables someone to achieve self-ownership. Second, Indifferenz does not mean indifference in the sense of not caring (in the ordinary sense of caring, not in Heidegger's distinctive sense of Sorge and its permutations). Thus, one can be quite excited, angry, disappointed, or distraught, etc., about certain entities in the world (e.g., certain events, what is going on at any moment in one's life, other people, or aspects of the world, etc.) that encounter and matter to one, and thus precisely not be indifferent (in the ordinary sense) to them, but without distinguishing oneself yet from others (e.g., SZ 126f., 168-170, 175). For example, one can care very much about who gets elected to become the next President of the USA, whether one's favorite sports teams win or lose, whether one can form meaningful relationships with particular individuals, etc., without yet really distinguishing oneself in Heidegger's sense from others. This may also explain why Heidegger chooses to use the Latinate word 'Indifferenz' rather than the ordinary German word 'Gleichgültigkeit' in picking out the phenomena on which he wants to focus in characterizing them as undistinguished ( $S Z \S \S 35-38)$. I will elaborate the 
more philosophical reasons for why Indifferenz and its cognates are better translated as 'undistinguishedness' and its cognates below.

This chapter is organized as follows. In section 2, I argue concisely that the social constitution interpretation of the relation between ownedness and unownedness is better supported by the textual evidence in Being and Time than the standard existentialist interpretation of their relation. In section 3, which is the heart of this chapter, I interpret in detail the presence and distinctiveness of undistinguishedness in Being and Time. In section 4, I reply to some objections that can be raised against my interpretation of undistinguishedness. Finally in section 5, I highlight some of the philosophical significance of undistinguishedness in ways that also address some criticisms of Heidegger's conception of human social existence in Being and Time, suggesting how my interpretation of undistinguishedness can defuse these criticisms or at least channel them in more nuanced directions. I conclude this paper by making some brief remarks about how the phenomena and idea of undistinguishedness can be a useful resource for contemporary (critical) social theories.

2 Textual Evidence and Interpretation I: The Existentialist and Social Constitution Interpretations of the Relation between Ownedness and Unownedness

No reader of Being and Time can fail to notice that Heidegger tends not only to distinguish everyday human existence as either owned or unowned, but also that he clearly valorizes, both rhetorically and philosophically, the owned mode of existence above the unowned. This he does despite his repeated insistence throughout the text that these descriptions are not meant to be disparaging and must be understood in their strict senses (SZ 42f., 175f.). Because there are so many passages in this text that clearly express this valorization of self-ownership or ownedness 
above unownedness, I cite now just two of them that are well known and also important for the purposes of this chapter. As Heidegger writes:

The self of everyday Dasein is the anyone-self, which we distinguish from the owned self, i.e., the self that seizes itself as its own. Dasein is in each case dispersed as the anyoneself and has then [erst] to find itself. This dispersion characterizes the 'subject' of the mode of being that we know as concernful absorption [besorgende Aufgehen] in the familiar world that shows up. (SZ 129)

In the same vein, Heidegger describes the 'falling' (Verfallen) of Dasein in connection with the unownedness of everyday existence as follows:

Dasein is initially and mostly amidst [bei] the 'world' that concerns it. This absorption amidst ... [Aufgehen bei ...] has mostly the character of being lost in the publicness of the anyone. Dasein as owned ability-to-be-a-self [eigentlichem Selbstseinkönnen] has initially always already fallen away from itself and fallen to the 'world'. The fallenness to the 'world' means absorption in being-with-one-another, insofar as this is guided by average talk [Gerede], curiosity, and ambiguity. What we called the unownedness of Dasein receives now a sharper determination through the interpretation of falling. ( $S Z$ 175f., second emphasis added)

These two passages provide us with the familiar and stark contrast between the owned self and the anyone-self, or more generally, ownedness and unownedness. It is very misleading to think that these terms mean, respectively, 'authenticity' and 'inauthenticity' for the following reasons. (1) It is nearly impossible for any competent English speaker to understand 'authenticity' and 'inauthenticity' in an evaluatively neutral way; English-speakers typically cannot help but associate 'authentic' with something good, worthy, genuine, or desirable, and 'inauthentic' with the polar opposites of these adjectives. But these terms, so translated, preclude in effect by way of sheer terminology a specific mode of human existence in the world that can be relatively evaluatively neutral (in a sense to be explained precisely in section 3 below), namely, undistinguishedness. (2) Just as problematically, these terms in English cannot help but evoke a Romantic conception of authenticity that emphasizes how someone can become a unique individual by finding and being true to his or her real self; a person is supposed to achieve this 
by turning radically inward and discovering his or her innermost and hence truest feelings, and then seeking to express this inner real self through his or her activities in the world. ${ }^{9}$ But this is a conception of authenticity that Heidegger actually rejects in Being and Time because his conception of self-ownership is much more demanding and, indeed, undermines all static conceptions of selfhood in general, whether 'authentic' or not. (Boedeker 2001: 96n35; cf. Blattner 2006: 160-167) (3) As the very first cited passage above explicitly states, 'eigentlich' for Heidegger means, strictly speaking, seizing a self as one's own (das eigens ergriffene Selbst) - in other words, pursuing the possibility of owning oneself, owning one's particular way of existing (cf. SZ 42). Accordingly, eigentliches Selbstsein (SZ 130) is better understood and translated as 'self-ownership' rather than 'authentic being-a-self' for the reasons just mentioned. (4) The distinction between 'authenticity' and 'inauthenticity' suggests (in Heidegger's terminology) ontical or 'existentiell' ways of existing for Dasein that are putatively exhaustive. But as we will see shortly, this is not the case, both interpretively and philosophically. In contrast to the existentialistic passages cited above, however, Heidegger also emphasizes the necessarily social constitution of the human being. Thus, he claims that Dasein is always already being with others ( $S Z$ §26), insofar as Dasein is being-in-the-world at all. For being-with (Mitsein) and the anyone are both 'existentials' (SZ 44f.), i.e., necessary enabling conditions of the possibility of being Dasein at all (SZ 120f., 129). As Heidegger writes in the following important passages:

The anyone is an existential and belongs as originary phenomenon to the positive makeup of Dasein.... Self-ownership [Das eigentliche Selbstsein] does not rest on an exceptional condition of the subject that is detached from the anyone, but is an existentiell modification of the anyone as an essential existential. (SZ 129f.; cf. 179 and 267; cf. also Heidegger 1989: 243)

\footnotetext{
${ }^{9}$ For informative explanations and modified defenses of this Romantic or expressivist conception of authenticity, see Taylor (1992) and Guignon (2004).
} 
Resoluteness [Entschlossenheit] means letting oneself be summoned from one's lostness in the anyone. ... Even the resolution [Entschluß] remains reliant on the anyone and its world. ... The resolution does not withdraw from 'reality', but uncovers only then what is factically possible; this resolution seizes what is factically possible in such a way that it grasps the latter as it is possible as one's ownmost ability-to-be in the anyone. (SZ 299; cf. 297f.)

These passages and others make it very clear that not only is ownedness not a possible mode of existing that can be completely detached from unownedness, but that ownedness can be achieved only against the background of one's absorption amidst unownedness, i.e., in the world, through a movement that puts a human being in the position to seize herself as genuinely her own from the anyone-selves that she primarily and mostly inhabits in everyday existence. This dependence of ownedness on unownedness also explains why the anyone is an existential, whereas the anyone-self, strictly speaking, is not (SZ 44f. and 129): The anyone has an ontological-existential status and is thus a necessary enabling condition for being Dasein at all, whereas the anyone-self has an ontic-existentiell status and expresses who we each primarily and mostly are over determinate stretches of time in concrete existence (cf. SZ 65). The anyone, then, circumscribes (prescribes and maintains) the range of concretely intelligible and thus really possible anyoneselves that are available in a particular culture for Dasein to assign to itself or just fall into. It effects this by normalizing - making average and thus common - the worldliness of the world, the referential nexus of significance (Verweisungszusammenhang der Bedeutsamkeit [SZ $§ 18]$ ) that conditions how oneself, other people, equipment, and one's wider surroundings hang together and make sense in a common and public manner. $(S Z 127)^{10}$ Although we are not powerless in response to the normalizing force of the anyone, such responses must always take their points of departure in relation to how the anyone governs and maintains the average everyday way in which the world has already been interpreted. As Heidegger writes:

\footnotetext{
${ }^{10}$ For an interpretation of the anyone that provides the extended argument for this conclusion, see Koo 2016.
} 
Dasein can never escape from the everyday interpretedness [Ausgelegtheit] in which it initially grows up. All genuine understanding, interpreting and communicating, rediscovering, and novel appropriating is carried out in, from out of, and against this everyday interpretedness. (SZ 169, emphases added)

There is thus a fundamental interdependence between being-with and the anyone, such that the human being always already coexists with others by understanding phenomena in the world and acting in relation to them in light of the background intelligibility that our familiarity with public and social norms (the anyone) provides (Boedeker 2001; Rousse 2013; Koo 2016).

3 Textual Evidence and Interpretation II: The Presence and Distinctiveness of Undistinguishedness (Indifferenz)

How does undistinguishedness fit into this account of the necessarily social constitution of the human being? In terms of textual evidence, besides the two passages already quoted above in section 1 of this chapter that explicitly mention its presence and distinctiveness ( $S Z 43$ and 53; cf. Heidegger 1989: 250f.), there is also the following important passage:

We determined the idea of existence as understanding ability-to-be, for which its own being itself is at issue. As in each case mine, however, ability-to-be is free for ownedness or unownedness or their modal undistinguishedness. [Als je meines aber ist das Seinkönnen frei für Eigentlichkeit oder Uneigentlichkeit oder die modale Indifferenz ihrer.] By beginning with average everydayness, the Interpretation thus far [i.e., in Division One of Being and Time] has restricted itself to the analysis of undistinguished or [bzw.] unowned existing. (SZ 232, last two emphases added)

These are the three passages in Being and Time that explicitly state that the human being can exist in three specific modes in her or his existence, one of which is undistinguishedness, not just in the modes of ownedness and unownedness.

An important textual clue that enables us to distinguish unownedness from undistinguishedness shows up in Heidegger's elaboration of being-there (Da-sein) as understanding, where he asserts that, 'Owned as well as unowned understanding can be in turn 
genuine or ungenuine [echt oder unecht].' (SZ 146; cf. 148) And as he writes informatively in

this connection in The Basic Problems of Phenomenology, which is worth quoting at length:

We understand ourselves in everyday life, as we can stipulate terminologically, not in an owned way in the strict sense of this word, i.e., not constantly from the ownmost and most extreme possibilities of our existence as our own, but rather unowned, indeed, to ourselves, in such a way that we are not ourselves as our own [wie wir uns nicht zu eigen]; rather we have lost ourselves in the everydayness of existing amidst things and people [emphasis mine - JJK]. Not owned means: not in such a way that we can at bottom [im Grunde] be ourselves as our own. Being lost does not have, however, a negative disparaging meaning, but means something positive that belongs to Dasein itself [emphasis mine - JJK]. Dasein's average way of understanding itself takes the self as an un-owned one [ein un-eigentliches]. This un-owned self-understanding does not mean at all an ungenuine self-understanding. ... Dasein's unowned self-understanding is neither ungenuine nor illusory [emphases mine - JJK], as though what is understood in this manner is not the self but something else, and the self only allegedly. Unowned selfunderstanding experiences [its] owned Dasein as such precisely in its peculiar 'actuality', if we may say so, and in a genuine way [emphasis mine - JJK]. The genuine actual, even though unowned, understanding of the self happens in such a way that this self, which we commonly exist from day to day, is 'reflected' from out of that [i.e., average everydayness] to which it has given itself over. (Heidegger 1989: 228; cf. 243) ${ }^{11}$

What is striking in these passages are the claims (1) that a self-understanding can be both unowned and yet genuine, as well as (2) how being unowned, in the sense of being lost in the average everydayness of human life (i.e., being lost in the anyone), does not have a disparaging meaning. Consequently, instead of a simplistic one-dimensional distinction between 'authenticity' and 'inauthenticity', as the standard existentialist interpretation of this distinction has it, we get textual evidence in this context that suggests a more nuanced matrix: ${ }^{12}$

\footnotetext{
${ }^{11}$ I thank Gerhard Thonhauser for drawing my attention to this important passage in Heidegger 1989.

${ }^{12}$ I am indebted originally to Dreyfus's eye-opening interpretation for my conception of this matrix (Dreyfus 1991: 192-194; cf. Käufer 2015: 103-111). That said, Dreyfus and I diverge somewhat regarding what phenomena should be placed in some of its boxes.
} 


\begin{tabular}{|c|c|c|}
\hline $\begin{array}{l}S Z \text { 146, 148, 187-191; } \\
\text { Heidegger 1989: } 228\end{array}$ & $\begin{array}{l}\text { Genuineness } \\
\text { (Echtheit) }\end{array}$ & $\begin{array}{l}\text { Ungenuineness } \\
\text { (Unechtheit) }\end{array}$ \\
\hline $\begin{array}{l}\text { Ownedness } \\
\text { (Eigentlichkeit) }\end{array}$ & $\begin{array}{l}\text { Self-ownership (by } \\
\text { undertaking } \\
\text { forerunning } \\
\text { resoluteness) } \\
\text { (Eigentliches Selbstsein } \\
\text { durch vorlaufende } \\
\text { Entschlossenheit) }\end{array}$ & $\begin{array}{l}\text { Experiencing anxiety about } \\
\text { being-in-the-world as such }\end{array}$ \\
\hline $\begin{array}{l}\text { Unownedness } \\
\text { (Uneigentlichkeit) }\end{array}$ & $\begin{array}{l}\text { Undistinguishedness } \\
\text { (Unownedness in the } \\
\text { pre-reflective, passive } \\
\text { sense): neither choosing nor } \\
\text { not choosing oneself as } \\
\text { one's own, but being lost in } \\
\text { the anyone because not yet } \\
\text { faced with anxiety } \\
\text { (Indifferenz der } \\
\text { Alltäglichkeit: alltägliches } \\
\text { Verlorensein im Man) }\end{array}$ & $\begin{array}{l}\text { Disownedness } \\
\text { (Unownedness in the } \\
\text { conscious, active sense): } \\
\text { after facing anxiety, } \\
\text { choosing to be lost and } \\
\text { remaining in (fleeing back to) } \\
\text { the anyone } \\
\text { (Flucht vor der Angst: } \\
\text { Abkehr vom eigentlichen } \\
\text { Selbstseinkönnen und } \\
\text { Rückkehr zum und } \\
\text { Wiederaufgehen im Man) }\end{array}$ \\
\hline
\end{tabular}

The meaning and relevance of the distinction between genuineness and ungenuineness will be explained below in due course. Meanwhile, we can make sense of the relation of undistinguishedness to disownedness and ownedness as follows. ${ }^{13}$ Initially and mostly, human

\footnotetext{
${ }^{13}$ I have benefitted especially from Blattner's insightful interpretation of their relations and differences, and take over, in particular, his introduction and use of a new term, namely, 'disownedness', for purposes of clarification and interpretation of the issues here (Blattner 2006: 127-167, and his 2013 and 2015).
} 
beings in their everyday lives are absorbed in the world by existing amidst the entities and people that matter to them. Thus they live initially and mostly in the undistinguished way in their lives, in the sense of being lost in the average everyday way of being in the world, including how they understand themselves and coexist with others in the world. According to Heidegger, unless human beings experience anxiety (in the sense that will be explained shortly), it is highly likely that they will continue to live and remain undistinguished in their existence. Undistinguishedness is thus the predominant way in which people are lost amidst the world by being the anyone-self in the world (SZ 129f.; cf. 189). In particular, living in the predominant and public mode of undistinguishedness implies that most human beings are not only unowned, but not even aware that they can live their lives in light of the choice of whether they choose to live in the owned or disowned way. Accordingly, this undistinguished way of being lost in the anyone is not actively chosen by human beings, but simply their passive, pre-reflective, and predominant way of being in the world. They are lost in this average everyday way of being in the world simply by growing up and living their lives in their given factical world (cf. SZ 12 and 42).

As the arrow pointing from undistinguishedness to anxiety in the matrix above indicates, it is only the experience of anxiety (Angst) that makes explicitly conscious and available to them their possibility of 'choosing to choose themselves': i.e., of truly individualizing themselves as distinct individuals who can own or disown their abilities-to-be-themselves. ${ }^{14}$ Briefly put, anxiety is an extraordinary affectivity (Befindlichkeit) of the human being, the experiencing of which forces the human being to come face to face with itself explicitly not only as beingpossible (Möglichsein) as such, i.e., the pure projecting of possibilities (cf. SZ §31), but also as

\footnotetext{
${ }^{14}$ Here and below, I am indebted to Han-Pile's rich and subtle examination (2013) of Heidegger's difficult idea of choosing to choose oneself. Her book chapter is very instructive as a whole.
} 
an entity that has the capacity and potential to own or not to own its concrete way of existing ( $S Z$ 187f.). As Heidegger writes:

Anxiety reveals in Dasein the being towards its ownmost ability-to-be, i.e., being free for the freedom of choosing and seizing itself [das Freisein für die Freiheit des Sich-selbstwählens und -ergreifens]. Anxiety brings Dasein face to face with its being free for ... (propensio in ...) the ownedness of its being as [a] possibility that it always already is [at bottom]. (SZ 188; cf. 268)

Only in anxiety lies the possibility of an outstanding disclosing, because it individualizes [vereinzelt]. This individualization brings Dasein back from its falling and makes manifest to it ownedness and unownedness [qua disownedness] as possibilities of its being. (SZ 190f., emphasis added; cf. 193) ${ }^{15}$

The first passage presents the complicated idea of the double choice or doubled structure of 'choosing to choose oneself': It is the experience of anxiety that explicitly opens up to particular human beings ('frees them for') the possibility of choosing, or not choosing, to achieve selfownership. Moreover, as the second passage here makes clear, prior to the experience of anxiety, human beings are not yet faced with the choice at all of whether to choose and seize themselves or not to do so, precisely because they have not yet experienced the unsettledness (Umheimlichkeit, Nicht-zuhause-sein [SZ 188]) that anxiety engenders. The experience of anxiety unsettles the familiar intelligibility of the everyday world as a whole, i.e., by rendering utterly insignificant how the world as a whole, up to that moment in time, has made sense and mattered to particular human beings, but in such a way that what remains, after this intelligibility has been rendered utterly insignificant through the experience of anxiety, is precisely the very worldliness of the world as interwoven with the human being's ability to be itself in the world as $\operatorname{such}(S Z 187)$.

\footnotetext{
${ }^{15}$ Notice in this particular passage that the experience of anxiety individualizes by revealing explicitly to Dasein both ownedness and unownedness (qua disownedness), not just ownedness, as possible ways in which it can concretely exist.
} 
There are two specific kinds of response to the experience of anxiety (as the two arrows pointing away from this experience in the matrix above indicate): Faced explicitly now with the choice of whether to choose to own oneself or not, one can either escape this extreme affectivity by fleeing from one's ability to achieve self-ownership and fleeing back to one's absorption in the anyone, in which case one consciously and actively disowns one's capacity and potential for self-ownership (SZ 189); or else one can seize this possibility by precisely undertaking forerunning resoluteness and thereby achieve self-ownership, owning up to one's way of being oneself in the world (SZ 298f.; cf. 308; cf. Blattner 2015: 128 and 130). Given that existing in the undistinguished mode covers up even the possibility of choosing whether to choose to own oneself or not, it is evident how the undistinguished mode differs starkly from the owned mode. But existing in the undistinguished mode also differs from existing in the disowned mode. As Béatrice Han-Pile puts it well, a human being who lives in the undistinguished mode,

[n] ot having been faced with explicit anxiety, ... does not have enough self-awareness to realize, even at a pre-reflective level, that there is a choice [about the possibility for selfownership] to be made. Note that it doesn't follow from this that the 'undistinguished' mode is evaluatively neutral; ... undistinguishedness can be construed as a motivated failure of self-knowledge. On such a picture, the undistinguished mode is also unowned but to a lesser degree, the significant difference with fully fledged disownedness being that undistinguishedness does not involve a violation of Dasein's epistemic standards, nor any deceptive intent: Dasein is motivated by its desire to maintain the more comfortable status quo of its immersion in the anyone into failing to see that it has a choice to make. But it is not aware of this failure to see and does not intend it. By contrast, [disownedness] involves both the ... awareness of the double choice [i.e., the choice of whether to choose to own oneself or not] and an intentional attempt to repress both this awareness and Dasein's choice not to choose itself. (Han-Pile 2013: 297) ${ }^{16}$

Now, as a quick aside, Han-Pile claims plausibly in this passage that existing in the undistinguished mode is not evaluatively neutral because it is a kind of 'motivated failure of self-

\footnotetext{
${ }^{16}$ I have taken the liberty of replacing Macquarrie and Robinson's translation of 'Indifferenz', 'Uneigentlichkeit', and 'das Man', respectively, as 'undifferentiatedness', 'inauthenticity', and 'the They' (Heidegger 1962), which Han-Pile cites in her text, with my preferred translation of these terms in Being and Time, for reasons already given above in this chapter.
} 
knowledge'. For existing in the undistinguished mode covers up, albeit in a pre-reflective and passive way, the human being's choice to choose itself or not (SZ 43, 176-178, 184). That said, Han-Pile also rightly emphasizes that undistinguishedness is unowned to a lesser degree than disownedness because human beings are not explicitly aware of this failure and do not deliberately bring this about. We can submit, therefore, that existing in the mode of undistinguishedness is relatively but not completely evaluatively neutral. For otherwise we would have to hold everyone blameworthy for all the pre-reflective unintended things of which they are unaware that they also happen to bring about in their lives. This would be a very, arguably overly, demanding standard to meet in going about how to live one's life. In any case, as Han-Pile convincingly argues, absent the recognition and appreciation of the significance of undistinguishedness as the third specific mode of human existence besides disownedness and ownedness, it would be very difficult to make sense of Heidegger's frequent talk of this double choice and its connection with possibility and freedom in Being and Time.

How does the distinction between genuineness and ungenuineness fit into this explanation of the relation between, or rather movement from, undistinguishedness to either ownedness or disownedness, at least for individuals who experience anxiety? Stephan Käufer (2015) has provided a helpful explication of the difference between genuineness and ungenuineness, on the one hand, and ownedness and disownedness, on the other. ${ }^{17}$ Whereas the distinction between ownedness and disownedness concerns whether a human being owns or does not own his or her factical existence (i.e., the degree of the mineness [Jemeinigkeit] of his or her existence), the distinction between genuineness and ungenuineness is broader by applying 'to interpretations of all kinds of things, not merely of existence, and captures whether the meaning

\footnotetext{
${ }^{17}$ Note that Käufer himself does not use the term 'disownedness' or its cognates in this book chapter.
} 
of an expression is properly tied to its underlying phenomena' (Käufer 2015: 103). As Käufer explains, the genuineness or ungenuineness of an understanding or interpretation for Heidegger depends on whether it is drawn from (geschöpft aus) the phenomena that it understands or interprets. Heidegger asserts in this connection that, 'Insofar as it is genuine [echt], talk [Rede] that lets things be seen (apophansis) should be such that what is talked about is drawn [geschöpft] from what one is talking about ...' (SZ 32, first emphasis added). More generally, Heidegger argues that an understanding or interpretation or, indeed, any approach or method in philosophy, counts as genuine in this sense only when it is adequate to the ontological constitution of the entities that concern it. As he writes:

Genuine method is grounded in the adequate preview [Vorblick] of the basic constitution [Grundverfassung] of the 'objects', or of the domain of such objects, to be disclosed. Genuine methodological reflection - which should be probably distinguished from the empty discussions of technique - gives, therefore, at the same time information about the mode of being of the entities that are thematized. (SZ 303)

Conversely, an ungenuine understanding, interpretation, approach, or method in philosophy is one that is not grounded in, and hence not adequate to, the ontological constitution of the entities that concern it. For example, as Heidegger argues extensively in Being and Time, a Cartesian or exclusively empirical approach to investigating the basic mode of being of the human being is fundamentally mistaken because their previews of the ontological constitution of the human being are radically inadequate to the distinctive mode of being of the human being $(S Z \S \S 9-10$, 13, 19-21, 43-44, 64). Consequently, such approaches in his view are ungenuine in this sense because they fail to draw properly from the relevant phenomena of human existence by assuming that the mode of being of such phenomena is present-at-hand (vorhanden) rather than being-inthe-world (SZ 12 and §9). 
In light of this explication, we can cast light on how human beings exist in the modes of undistinguishedness, ownedness, and disownedness, now under the aspect of the genuineness or ungenuineness of these three modes of human existence. Undistinguishedness characterizes the average everydayness of Dasein's existence and thus articulates the unitary existential structure of Dasein that we get in Division One of Being and Time (SZ 232). Heidegger would surely claim that although this unitary structure articulates the unowned mode of existence, it is still genuine because the existentials that he specifies in Division One draw properly from the relevant phenomena that constitute and thereby make human existence possible at all. His insistence that we must distinguish sharply between existentials (ontological determinations of Dasein) and categories (ontological determinations of non-Dasein entities) expresses his claim to the genuineness of the existential analytic of Dasein (SZ 44f.). For if this analytic in Division One had not been genuine in the sense expressed above, the very method of hermeneutic phenomenology (SZ §7) and the aims announced in Being and Time would not have even made sense as a philosophical project. Similarly, it should not be hard to understand why selfownership (ownedness) is genuine in this sense: For self-ownership as another specific mode of human existence is adequate to the ontological constitution of Dasein by actualizing Dasein's distinctive possibility of choosing to own itself through forerunning resoluteness, a possibility that derives intrinsically from Dasein's ontological constitution in that Dasein is ontologically co-determined by mineness ( $S Z$ 42f.). In other words, owned Dasein actualizes a possibility that is built in or structural to Dasein's very ontological constitution, a concrete way of existing that, when actualized, is both owned and genuine (Richardson 2012: 168; cf. 131).

Conversely, disownedness is evidently unowned but also ungenuine for the following reason: When Dasein after experiencing anxiety flees from its choice to choose itself and flees 
back to the tranquilization and comfort that existence as being lost in the anyone provides, it shows itself as not only lacking courage, but malfunctioning as the entity that it fundamentally is by choosing not to be fully adequate to its ontological constitution as the entity for whom in its being its own being itself is at issue ( $S Z 12$ and 42). Taking advantage of the double meaning of 'eigentlich' in German, in terms of its colloquial usage and how Heidegger exploits its etymology, Heidegger writes the following regarding what it is to own oneself: 'Dasein is actually/ownedly itself [ist eigentlich selbst] in the originary individualization of a resoluteness that is ready for anxiety in a reticent way.' (SZ 322) This implies that the Dasein who chooses not to be resolute and thereby not to seize itself as its own does not fully actualize its self in accordance with a possible way of concretely existing that its ontological constitution makes intrinsically available (cf. Käufer 2015: 104).

Finally, the experience of anxiety has the character of being owned but ungenuine for presumably two reasons. On the one hand, Dasein becomes explicitly aware in experiencing anxiety that it has the choice to choose or not to choose itself; Dasein becomes thus consciously aware of the possibility that it can achieve self-ownership. On the other hand, Dasein is presumably ungenuine in experiencing anxiety because this extraordinary affectivity, while bringing Dasein closer to actualizing a possibility made intrinsically available by its very ontological constitution, does not yet fully actualize this possibility. In other words, the experience of anxiety is not yet fully adequate to, in the sense of fully fulfill or actualize, the intrinsic concrete (existentiell) possibility of self-ownership that is built in or structural to its mode of being as such (Richardson 2012: 144). Although the experience of anxiety brings one closer to actualizing the possibility of self-ownership, it is and remains ungenuine because this 
affectivity does not yet live up to the full ontological potential that is available as a concrete (existentiell) possibility in Dasein's basic mode of being as existence (being-in-the-world).

In summary, what emerges in the matrix presented above are three specific modes of concrete (factical, existentiell) human existence, namely, undistingushedness, ownedness, and disownedness, instead of just 'authenticity' and 'inauthenticity' as a mutually exclusive opposition, as the standard existentialist interpretation has it. It is important to bear in mind that although the experience of anxiety occupies one of the four boxes in the matrix presented above, it is very hard to conceive how such experience can be a stable or persistent mode of concrete existence because anxiety can only be an intermittent affectivity on account of its extraordinary, because radically unsettling (unheimlich), character (SZ 190). ${ }^{18}$ For it is very difficult to imagine how one can exist continuously in any meaningful way when the world in its worldliness as a whole becomes utterly insignificant to oneself. In stark contrast with the experience of anxiety, undistinguishedness, disownedness, and ownedness do not just retain but are committed (to be sure, each in its own specific manner) to a human being's ability to be a self in the world that is and remains significant to him or her. The experience of anxiety cannot be, therefore, a fourth specific mode of human existence because of its radical unsettledness. ${ }^{19}$ What is above all crucial to note is that we have now discerned and elaborated two ways of being unowned: an undistinguished, i.e., pre-reflective and passive, way of being unowned that is not yet explicitly aware of, and hence faced with, the choice of whether to choose oneself or not; and a disowned, i.e., conscious, active, and thus egregious, way of not wanting to individualize oneself and

\footnotetext{
${ }^{18}$ Blattner (2006: 139-144) argues plausibly that anxiety is, therefore, equivalent to psychological depression, which empirically speaking is an attitude toward the world that seems relatively persistent in depressed individuals. But notice that such individuals struggle with living in their lives with this general outlook on life and seek continually to try to escape it or at least keep it at bay.

${ }^{19}$ I thank Søren Overgaard for making me think hard about this issue.
} 
potentially own one's existence. For the purpose of disambiguation, then, unownedness should be understood as a genus with two species, which we have terminologically distinguished by calling one species 'undistinguishedness' and the other 'disownedness'.

\section{Replies to Objections}

Some likely objections can be raised in response to my argument about the presence and distinctiveness of undistinguishedness as the third specific mode of human existence in Being and Time. To begin with, one may object that Heidegger's talk of the undistinguishedness of everydayness serves only a methodological purpose: ${ }^{20}$ Its primary goal is to analyze the average everyday way in which human beings exist in abstraction from the distinction between ownedness and disownedness, not to claim that human beings can actually live concretely in the mode of undistinguishedness. This interpretation is given some support by the rarity with which Heidegger explicitly characterizes the existential analytic of Dasein as undistinguished in Being and Time, not to mention that he himself characterizes this analytic as preparatory (vorbereitend [SZ 41 and 232]), suggesting thereby that it is a means to some further set of philosophical ends. In short, the objection is that undistinguishedness plays at most a methodological role in the text by abstracting from ownedness and disownedness as (supposedly) the only two possible specific modes of human existence.

In response to this objection, recall first Heidegger's assertion, in the course of making the transition from the concerns of Division One to those of Division Two in this text, that, 'As in each case mine, however, [Dasein's] ability-to-be is free for ownedness or unownedness or

\footnotetext{
${ }^{20}$ I thank Christian Schmidt for raising this objection, although he does not spell out the line of thought that presumably underlies his query in the way that I do here. Magid also makes this objection (2015: 11), although it does not feature as a main element in his line of argument, as far as I can tell.
} 
their modal undistinguishedness [Als je meines aber ist das Seinkönnen frei für Eigentlichkeit oder Uneigentlichkeit oder die modale Indifferenz ihrer].' (SZ 232, last emphasis added). In light of this passage, does it make sense really to think that Dasein is free for undistinguishedness as an abstraction? (Blattner 2015: 133n12) How can any human being be free for an abstraction, especially when it comes to how the human being concretely exist? It is beyond doubt that Heidegger claims that the existential analytic of Dasein that he provides in Division One of Being and Time is meant to describe how human beings concretely exist and act in the world ( $S Z$ $\S \S 12-13)$. Furthermore, Heidegger states explicitly and repeatedly that ownedness and unownedness modify in an existentiell manner the undistinguishedness of everydayness ( $S Z$ 43, $130,179,267,297-299,305,309)$. This statement presupposes the lived experience and actuality of undistinguishedness, not its abstraction from the latter: 'This undistinguishedness of everydayness is not nothing, but a positive phenomenal character of this entity [i.e., Dasein]. All existing, as it is, comes from out of this mode of being and back into it.' (SZ 43, second emphasis added) By emphasizing that all concrete existence comes from out of the undistinguishedness of everydayness and back into it, Heidegger makes it very clear that undistinguishedness cannot be an abstraction from concrete human existence, but is instead its starting-point and basis. Consequently, it is mistaken to understand undistinguishedness as performing a merely methodological role that abstracts from actual concrete human existence.

Oren Magid (2015) has recently made a series of objections to the claim about the distinctiveness of undistinguishedness. ${ }^{21}$ His main conclusion is that whenever Heidegger describes Dasein's existence in the mode of undistinguishedness, the latter phenomenon is better

\footnotetext{
${ }^{21}$ In this article, Magid takes over Macquarrie and Robinson's translation of 'Indifferenz' and its cognates as 'undifferentiatedness' and its English cognates. Because his and my interpretations of Indifferenz are opposed, I will cite textual passages from him without substituting my preferred translation for terms like 'Indifferenz',

'Uneigentlichkeit', etc.
} 
understood as 'indifferent inauthenticity', which is after all a mode of 'inauthenticity'. His claim is that 'indifferent inauthenticity' cannot be a distinct 'undifferentiated' mode of existence that can be 'neither authentic nor inauthentic' (Magid 2015: 3 and 10). Magid seems to give three direct, specific arguments for this conclusion. First, he claims that the meaning of 'not authentic' is fully interchangeable with 'inauthentic', leaving thereby no room whatsoever for any other mode of concrete human existence:

When Dasein understands itself 'not authentically', it understands itself 'inauthentically'. Heidegger also tells us explicitly and in no uncertain terms that Dasein's average everyday self-understanding - a self-understanding whose averageness ... amounts to 'indifference' - is inauthentic. ... This explanation of the terms renders Dasein's selfunderstanding always either authentic or inauthentic. Heidegger explicitly identifies selfunderstanding that is not authentic with that which is inauthentic: not authentically = inauthentically. This leaves no conceptual room for a third, undifferentiated mode of existence, one that is neither authentic nor inauthentic. (Magid 2015: 5f., all emphases in the original).

Given how 'Uneigentlichkeit' and 'Eigentlichkeit' and their cognates are translated as 'authenticity' and 'inauthenticity' into English, Magid's argument here can seem to be obviously sound in virtue of sheer terminology. But this is why the careful translation of such terms is neither linguistically nor philosophically trivial. As mentioned already above in section 1 of this chapter, the distinction between 'authenticity' and 'inauthenticity' expresses a mutually exclusive opposition that claims to exhaust all manifestations of the phenomena in question. But as I (and others) have argued, a careful reading of the text gives evidence that this is not the case. More importantly, Magid's argument here, seemingly by means of terminological stipulation, begs the question regarding whether Uneigentlichkeit and Eigentlichkeit exhaust all the ways in which human beings concretely exist. In particular, it occludes, by means of such stipulation, how there can be two distinct ways in which human beings exist as unowned: namely (in my vocabulary and as I argued in section 3), undistinguishedness and disownedness. 
In fairness, Magid does mention and briefly elaborates a distinction between 'indifferent inauthenticity' and 'non-indifferent inauthenticity', so he, too, makes space in his interpretation for two different ways of being 'inauthentic' (Magid 2015: 14-16). He characterizes 'nonindifferent inauthenticity' as the situation in which Dasein becomes aware that it cannot be indifferent to the possibility of 'authentic self-understanding' (i.e., self-ownership) and can seek to realize the latter, though, without any guarantee of success. There is thus conceptual space in Magid's interpretation for possibilities that seem similar to the distinctions that I made above in section 3 between the experience of anxiety, disownedness, and ownedness. That said, he oddly in this context does not mention and elaborate the crucial significance of anxiety at all, much less explore the role that the distinction of genuineness and ungenuineness can be interpreted as playing in this context. As far as this first specific argument of Magid is concerned, then, it is not yet convincing because at best it either postpones further arguments that need to be made for its conclusion, or else says too little about the issue of how there can be two modes of concrete human existence that are 'inauthentic' or, better, unowned in different ways.

Now, Magid does proceed later in his article to make a second argument for his conclusion that Dasein can never exist concretely in the 'undifferentiated' mode, one that does not depend on terminological stipulation. As he argues:

Because of the stance the average, indifferent self-understanding takes towards its own being, it can countenance neither the possibility of authentic nor inauthentic selfunderstanding. ... It is indifferent to the distinction. Given Heidegger's elucidation of the meaning of 'indifference', we have no reason to think that in this average everyday indifference, Dasein's self-understanding is neither authentic nor inauthentic. Instead, Heidegger's discussion suggests that though average everyday Dasein does not differentiate between these possibilities of self-understanding as it understands itself 'without further ado', its being remains 'at any time differentiable ${ }^{22}$ nonetheless. Crucially, it is precisely this failure to differentiate between authentic and inauthentic self-understanding that accounts for average everyday Dasein's inauthenticity. ...

\footnotetext{
${ }^{22}$ This phrase quotes part of a sentence in Heidegger 1989: 250.
} 
Average everyday Dasein is indifferently inauthentic. (Magid 2015: 10, all emphases in the original)

Magid is certainly right that 'indifferent' or undistinguished Dasein exists as such because it is unaware of the choice to choose itself: Everyday Dasein is lost in an average way in the anyone (SZ 189) on account of its unavoidable absorption amidst the world, which covers up the availability and urgency of this double choice for Dasein. Magid's argument here is thus on firm ground insofar as it claims that Dasein is (in his terms) 'indifferently inauthentic' precisely because (in my terms) it is unowned by not being confronted yet with the experience of anxiety about the choice to choose or not to choose itself. Moreover, Magid has also rightly identified some interpreters of Being and Time as claiming that existing in the 'undifferentiated' or undistinguished mode implies that one exists in a way that is 'neither authentic nor inauthentic' (Magid 2015: 2n1). ${ }^{23}$ It is to Magid's (and, as we saw above, Han-Pile's) credit, then, to emphasize that existing in the undistinguished mode cannot be completely evaluatively neutral. That said, this concession also makes available at the same time a more careful and nuanced characterization in this context: Human existence in the mode of undistinguishedness is not completely but only relatively evaluative neutral regarding the extent to which undistinguished human beings take responsibility for their concrete way of existing, for reasons that Han-Pile has plausibly given. If so, this suffices to create determinate space for the presence and distinctiveness of undistinguishedness, for which I have argued in section 3 above. I submit, then, that the discernment and articulation of how there can be two related but distinct ways in which human beings are unowned makes better sense of Being and Time as whole; it also enables the philosophical insights of this dimension of the text to emerge more clearly by differentiating

\footnotetext{
${ }^{23}$ The most prominent among them that he mentions in this footnote are Dreyfus (1991), Blattner (1999), and Carman (2000: 15 and 24). I myself have also made this claim elsewhere in a recent chapter (Koo 2016: 109-112). Thanks to Magid's and Han-Pile's interpretations, what I write immediately below modifies the force of this claim.
} 
the generic phenomenon of unownedness from its species, namely, undistinguishedness and disownedness. This interpretation is also strengthened by integrating the significance that other interpreters of Being and Time have given to Heidegger's difficult idea of the choice to choose oneself and the important role that anxiety plays in the movement from undistinguishedness to ownedness and disownedness. Although Magid himself makes room for two different ways for Dasein to be 'inauthentic' ('indifferent and non-different inauthenticity'), it remains unclear how his distinction connects with the insightful interpretations of these key ideas in Being and Time.

Finally, Magid's third argument for his conclusion turns on how we should understand Heidegger's use of the word 'bzw.' (= 'beziehungsweise') in the few passages in which Heidegger writes explicitly that Dasein exists as (or is free for being) owned or unowned or (bzw.) their modal undistinguishedness:

By beginning with average everydayness, the Interpretation thus far [i.e., in Division One of Being and Time] has restricted itself to the analysis of undistinguished or [bzw.] unowned existing. (SZ 232, last two emphases added; cf. 53)

Magid argues that ' $b z w$ ' in this and other relevant passages in Being and Time should be understood as expressing its elaborative sense as meaning 'or rather', ' better said', or 'more precisely', not its disjunctive sense as meaning 'in the other case' (Magid 2015: 13). Accordingly, he claims that the phrase 'undistinguished or [bzw.] unowned existing' should be understood in the elaborative sense of ' $b z w$.' as 'of indifferent or rather, or better said, or more precisely, inauthentic existing'; on Magid's reading, then, ' $b z w$. ' is understood as a conjunction, such that 'indifference' is ultimately a prevalent form of 'inauthenticity'. What is at stake here is not trivial, but concerns, indeed, the proper interpretation of the few explicit pieces of textual evidence for whether there are two or rather three modes of concrete human existence that Being and Time makes available as different kinds of possibilities for Dasein. Basically, Magid's 
argument here is that since he has already shown that Dasein's modal 'undifferentiatedness' amounts to its 'indifferent inauthenticity' (the second argument sketched and assessed just above), which is in turn, in terms of content and by way of terminology, a specific mode of 'inauthenticity' (the first argument sketched and assessed above), this shows that Dasein's modal 'undifferentiatedness' cannot be fundamentally distinct from 'inauthenticity' since it is after all a species of the latter. (Magid 2015: 14).

It is far from clear, however, that the elaborative sense of ' $b z w$.' is the better hermeneutic choice over its disjunctive sense regarding how we should understand its uses in this and other passages that are relevantly similar. First of all, other renderings of the disjunctive meaning of ' $b z w$. ', in addition to 'in the other case', include 'or respectively', 'or as the case may be', or 'the same item but under different circumstances', all of which actually correspond much closer at least to its usages in colloquial German. Moreover, it may well be that while undistinguishedness is certainly related to disownedness, the former is also importantly distinct from the latter in significant ways (as I argued in section 3 above). If so, the ' $b z w$.' that connects (in Magid's terms) 'indifference' and 'inauthenticity' is not interchangeable, but expresses how the manner of unowedness in undistinguishedness is importantly different from that in disownedness. More generally, philosophical interpretations, arguments, and assessments are very rarely settled just by considering linguistic usage per se, but depend ultimately on how much illumination they cast on the text and how well such illumination is also supported and defended by the fruitfulness of the interpretation that makes use of it. If the line of argument in section 3 is convincing, it shows that it is more illuminating to interpret the uses of ' $b z w$.' in these contexts in its disjunctive sense, for reasons given and defended in that section. If so, the question of whether Being and Times makes room for two or rather three specific modes of human existence cannot be settled 
by recourse solely to linguistic usage concerning the word ' $b z w$.', but can only be evaluated on hermeneutical grounds regarding how best to interpret Being and Time. In sum, while these objections certainly advance the debate in question, none of them are convincing upon examination.

5 Philosophical Significance and Resource for Contemporary (Critical) Social Theory

Now that we have seen how there is definite, albeit infrequent, textual evidence in Being and Time for the presence and distinctiveness of undistinguishedness from ownedness and especially disownedness, the question arises about why this matters. That is, why does it matter philosophically if we discern undistinguishedness as a specific and, indeed, predominant (average everyday) way in which human beings concretely exist that is related to but distinct from ownedness and disownedness? I believe there are at least three consequences that are philosophically significant in direct connection with understanding Being and Time, with a fourth that makes a transition to the potential of undistinguishedness as a resource for contemporary (critical) social theories.

First, differentiating undistinguishedness from ownedness and disownedness enables us to bring into the foreground how the predominant way in which Dasein concretely exists is relatively but not completely evaluatively neutral and thus undeserving of total condemnation, even though, to be sure, it remains unowned (in the pre-reflective passive sense of unownedness). Otherwise, absent the discernment of undistinguishedness in everyday human existence, we are left with the stark dichotomy between 'authenticity' and 'inauthenticity', a mutually exclusive binary that is too one-dimensional and devoid of nuance, thereby oversimplifying and distorting the predominant way in which human beings concretely exist. Put 
simply, according to this one-dimensional existentialist interpretation of these two modes of human existence, most human beings are 'inauthentic' because they conform to the dictates of the Crowd and can only achieve 'authenticity' by rejecting the expectations and demands of our social environment through radical self-individualization. On this view, I can become truly myself only by becoming a unique individual, which eo ipso requires my radical non-conformity to the expectations and demands of others in society.

The most important problem with this view is that it cannot make room for the necessarily social constitution of the human being, not just in his or her early upbringing but going forward as adults in their lives. It is precisely to Heidegger's credit in Being and Time that he shows us how the human being is necessarily socially constituted by way of arguing that the very intelligibility of the world in its worldliness depends on how we each initially and mostly exist in a common world with others. The key move of this argument is that we are each already with others just by making sense of the world as such, i.e., by being-in-the-world as such. How so? Because our affective-projective understanding of the world cannot help but already draw in public and social norms that the anyone supplies in our very comportment toward the world at all. But the one-dimensional binary of 'authenticity' and 'inauthenticity' requires that insofar as we draw on any social resources for making sense of anything, we are eo ipso 'inauthentic'. Given our necessarily social constitution, discerning the undistinguished way in which we are unowned in this pre-reflective passive sense enables us to do justice to the fundamentally social dimension of our existence without outright condemnation of this existence as such.

A second philosophical consequence of differentiating undistinguishedness from disownedness is that this move makes room in our concrete existence for ways of 'leaping in' and caring for others (die einspringend-beherrschende Fürsorge) that are not wholly pejorative. 
In Heidegger's description of this mode of caring for others (Fürsorge), he chooses not to focus on positive aspects in which we can 'leap in' for others and only highlights, unjustifiably, the negative ones: namely, how 'leaping in' for others in this sense makes the people for whom one cares dependent on and dominated by the person who 'leaps in' for them. Prima facie, then, it seems that this view precludes any positive modes of 'leaping in' and caring for others.

Two responses can be given to this objection. First, Heidegger himself notes in passing that this description of 'leaping in' for others is extreme and that there are many mixed forms of caring for others that combine 'leaping in' and 'leaping ahead' (die vorspringend-befreiende Fürsorge) for others as modes of concrete coexistence with them (SZ 122). Thus, there is actually space in his conception of being-with-others that can regard 'leaping in' and caring for others in a positive light, provided presumably that this is carried out in a way that is reasonable and unoppressive. Second and relatedly, in terms of concrete examples, we merely need to consider parents, other caregivers, teachers, mentors, friends, colleagues, life-partners, etc., who often initially or continually 'leap in' for others about whom they care deeply, in the best sense of 'leaping in', of course. Oftentimes, people in such roles initially 'leap in' for others with the intent at least, though, of course, not the guarantee of the actual result, of eventually enabling those for whom they 'leap in' to flourish as the best human beings they can become. Now, this possibility of being with others can seem to come close to what is involved in 'leaping ahead' for others. But it cannot be the latter (at least not yet) because it is rare, though not impossible, that those in such roles who 'leap in' for others with the intent of enabling them to flourish do so by being their 'conscience' (in accordance with Heidegger's conception of conscience) and thereby inspiring them to achieve self-ownership (SZ 298). As we can imagine, 'leaping ahead' for others (i.e., being their conscience in this rarefied sense) is not only hard to do for the person 'leaping 
ahead', but also very hard for the people whom this comportment is meant to benefit, given that such comportments requires undertaking forerunning resoluteness (vorlaufende Entschlossenheit). Consequently, Heidegger's position in Being and Time implicitly makes room for, and our factical existence has already experienced, modes of caring for others (Fürsorge) that are situated between the extreme possibilities of 'leaping in' and 'leaping ahead' for them. I think it is not hard to conceive how these mixed modes of being-with-others are of a piece with the undistinguished mode of everyday existence. Let us not idealize them, however; there are clearly some people who live in this mode and are ethically better than others in terms of what they do in their lives (thus some parents, caregivers, teachers, mentors, friends, life-partners, etc., are clearly better than others). It is admittedly hard to find textual evidence for this idea in Being and Time, but I have just argued that it is compatible with the spirit of Heidegger's way of thinking in this text.

A third reason that differentiating undistinguishedness from ownedness and disownedness is significant is that this move enables us to defuse a familiar line of criticism of Heidegger's conception of human social existence. Indeed, this line of criticism was already made by Karl Löwith in his Habilitation, with Heidegger himself as its main supervisor and coevaluator, published in 1928 as Das Individuum in der Rolle des Mitmenschen (Löwith 2013), so just a year after the publication of Being and Time. Without going into details, Löwith was perhaps the first among many prominent philosophers (e.g., Buber, Arendt, Levinas, Adorno, Marcuse, Habermas, Theunissen, Tugendhat, Rentsch) to criticize, with philosophical and often (understandably) personal and political vehemence, and each in quite different ways, Heidegger's conception of human social existence in Being and Time as a seriously distorted and hence mistaken understanding of this existence. This is not the place to engage their critiques, 
and there is surely something penetrating and right about them in some shape or form, given the power of the thoughts of these thinkers. Having said that, I would argue that almost every single one of these prominent philosophers takes for granted that Heidegger only conceives of two modes of human existence, namely, 'authenticity' and 'inauthenticity'; they all assume that the standard existentialist reading of Being and Time is a more or less accurate reading of it that captures its main thrust and key points. To my knowledge, however, none of them notice or make much of the undistinguishedness of everydayness as the third mode of everyday human existence with philosophical import or ramifications, which admittedly is largely Heidegger's own fault in Being and Time for reasons presented above.

What could have happened, though, had they also discerned and taken into account undistinguishedness as the third mode of human existence in Heidegger's Being and Time? Could its discernment in that text, according to the interpretation of it that has been presented above, have defused, or at least rendered more nuanced, the forthright critiques of these philosophers of Heidegger's alleged dismissal of the positive dimension of human social existence? I think it is plausible to think that this could have happened, for undistinguishedness seems to overlap partially, to be sure in altered modes, with some elements of the critical standpoints of these philosophers (though there is obviously no space to explore this here).

This thought leads to a fourth reason why undistinguishedness is philosophically significant, this time in terms of its use for contemporary (critical) social theory. It is helpful to understand why by explaining it initially with a likely consequence of working with the onedimensional evaluative standard to which the binary of 'authenticity' and 'inauthenticity' leads. It seems hard to envisage how the use of such a standard to evaluate the quality and well-being of a human being or, collectively speaking, of a community or society of human beings, cannot 
but help but result in an overly individualistic assessment of human flourishing. This does not mean that the 'authentic' individual must be committed only to individualistic ends, but rather that the source and medium of that commitment must be and remain individualistic. Even when Heidegger writes about how 'authentic' individuals can be the 'conscience' of others (SZ 298) most notoriously in $§ 74$ of Being and Time about how they can not only seize their own individual 'fates' (Schicksale) by being 'authentic', but also, as members of a common generation, appropriate 'authentically' their collective 'destiny' (Geschick) as a community and a 'people' (Volk) - what he writes on this particular topic is much too brief and underdeveloped, let alone well defended. A serious and alarming question in this context concerns whether this conception of interpersonal and communal flourishing (if it is that at all) can be evaluated other than by way of an uncontested agreement about what this 'destiny' is or should be. But this view is highly problematic in all sorts of ways that go way beyond the scope of this chapter.

After all is said and done, undistinguishedness still remains a mode of unownedness in the pre-reflective passive sense. Human beings who are undistinguished in this sense continue to live their lives in accordance with the public and social norms, expectations, and practices of the factical world in which they are thrown and in terms of which they typically understand their lives and act. They are immersed in and largely constituted by the normalization of the factical world in which they live, including how others and they make sense of one another and themselves. This is one of the key points of emphasizing that the anyone prescribes the typical intelligibility of the world, i.e., that it is the anyone-self that articulates the referential nexus of significance (Verweisungszusammenhang der Bedeutsamkeit) of that world (SZ 129). For this reason, living in an undistinguished way is necessarily complicit with the normalized - i.e., publicly and socially normative - way in which factically the world in its worldliness makes 
sense to and of us. It follows that being undistinguished is complicit, by and large, with the social practices and social structures that normalize ('socialize') people, say, as those having certain individual and collective attitudes toward human life and what is taken to be important in it, and also as members of a social class, an ethnicity or a race, a gender, etc. Thus, undistinguishedness is both the initial medium and probable outcome of ongoing social conditions that contribute to the rise of certain socioculturally specific attitudes about how one should live, as well as differential (unequal) access to material and cultural capital and their attendant privileges or the lack thereof.

In this connection, the critical potential of undistinguishedness in my view consists not in providing some prescriptively normative standard, i.e., a set of prescriptively normative principles, about how we should live and act, but rather in how we can be better equipped to understand human social existence by examining and questioning ways in which it is mostly hidden, i.e., not fully consciously lived. In other words, its critical potential consists more in getting us to become much more aware of and change, when justified, the general underlying "thick" assumptions on the basis of which we pre-reflectively understand and explain the social dimension of human existence in its myriad complexities and tensions. Specifically, mobilizing the critical potential of undistinguishedness involves, first, the necessity of understanding this dimension by beginning with the understanding of its worldliness, not with that of how people interact with one another in abstraction from this worldliness. That is, we need to examine the collective expectations, norms, and practices - the public and social sources of normativity (normalization) - that shape people, for better or worse, into the kinds of people that they are, 
and this often at levels of which they are not conscious. ${ }^{24}$ In order to do so, I suggest that we need to examine the way in which people live in the undistinguished mode of existence.

Second, undistinguishedness also can be theoretically useful for social theory by enabling social theorists or social scientists to explain how individual agents relate in complex ways to the social structures that are both the medium and the outcome of their actions. The social theories of Pierre Bourdieu and Anthony Giddens, for example, have appropriated this idea in terms of what they, respectively, call habitus and structuration (Bourdieu 1992; Giddens 1979, 1984). It is easy to see how undistinguishedness plays a central role in these social theories, along with the emphasis on how at once social norms (the anyone) inform habitus and structuration and are also effected by them. Third and lastly, being attentive to how public and social normativity (normalization) functions as undistinguishedness equips critical social theorists to reveal the insidious ways in which public and social normativity at once constitutes and subjugates us in ambivalent and oppressive ways (Young 1990; Butler 1990; Alcoff 2006; Haslanger 2012). This is also what attentiveness to the phenomena of the undistinguishedness of everydayness opens up as resources for contemporary critical social theories. ${ }^{25}$

\footnotetext{
${ }^{24}$ In Foucault's terms, we need to understand and criticize how human beings are made into subjects who are the effects of the exercise of disciplinary power in different spheres of society and human life (Foucault 1977, 1978, 1983).

${ }^{25}$ I have benefited much from the questions and comments of two groups of audience to whom previous versions of this paper were presented: the first at the original workshop focusing on Heidegger's conception of the anyone and its relevance for contemporary social theory at the University of Vienna in December 2014; and the second subsequently at the Center for Subjectivity Research at the University of Copenhagen in June 2016. I also thank Gerhard Thonhauser and an anonymous reviewer of the penultimate version of this paper for helpful comments. Last but not least, I wish to thank Gerhard Thonhauser and Hans Bernhard Schmid, as well as Dan Zahavi, for their respective invitations to me to present this work on these occasions.
} 


\section{REFERENCES}

Alcoff, Linda. 2006. Visible Identities. Oxford and New York: Oxford University Press. Blattner, William. 1999. Heidegger's Temporal Idealism. Cambridge: Cambridge University Press.

-----. 2006. Heidegger's Being and Time. London and New York: Continuum.

-----. 2013. Authenticity and Resoluteness. In The Cambridge Companion to Heidegger's Being and Time, ed. Mark Wrathall, 320-337. Cambridge: Cambridge University Press. -----. 2015. Essential Guilt and Transcendental Conscience. In Heidegger, Authenticity and the Self, ed. Denis McManus, 116-134. London and New York: Routledge.

Boedeker, Edgar. 2001. Individual and Community in Early Heidegger: Situating das Man, the Man-self, and Self-Ownership in Dasein's Ontological Structure. Inquiry 44: 63-99.

Bourdieu, Pierre. 1992 [1980]. The Logic of Practice. Trans. R. Nice. Stanford: Stanford University Press.

Butler, Judith. 1990. Gender Trouble. New York and London: Routledge.

Carman, Taylor. 1994. On Being Social: A Reply to Olafson. Inquiry 37: 203-223.

-----. 2000. Must We Be Inauthentic?. In Heidegger, Authenticity, and Modernity, eds. Mark Wrathall and Jeff Malpas, 13-28. Cambridge: Cambridge University Press.

-----. 2003. Heidegger's Analytic. Cambridge: Cambridge University Press.

-----. 2005. Authenticity. In A Companion to Heidegger, eds. Hubert Dreyfus and Mark Wrathall, 285-296. Malden (USA) and Oxford: Blackwell.

Christensen, Carleton. 2012. The Problem of das Man - A Simmelian Solution. Inquiry 55: 262-288.

Dostal, Robert. 1982. The Problem of 'Indifferenz' in Sein und Zeit. Philosophy and Phenomenological Research 43: 43-58.

Dreyfus, Hubert. 1991. Being-in-the-World. Cambridge (USA): MIT Press.

-----. 1995. Interpreting Heidegger on das Man. Inquiry 38: 423-430.

Egan, David. 2012. Das Man and Distantiality in Being and Time. Inquiry 55: 289-306.

Figal, Günter. 1991 [1988]. Martin Heidegger. Frankfurt/Main: Anton Hain.

Foucault, Michel. 1977 [1975]. Discipline and Punish. Trans. A. Sheridan. New York: Vintage Books.

----- 1978 [1976]. The History of Sexuality, vol. 1. Trans. R. Hurley. New York: Vintage Books.

-----. 1983, $2^{\text {nd }}$ ed. [1982] The Subject and Power. In Foucault: Beyond Structuralism and Hermeneutics, eds. Hubert Dreyfus and Paul Rabinow, 208-228. Chicago: University of Chicago Press.

Freeman, Lauren. 2011. Reconsidering Relational Autonomy: A Feminist Approach to Selfhood and the Other in the Thinking of Martin Heidegger. Inquiry 54: 361-383.

Giddens, Anthony. 1979. Central Problems in Social Theory. Berkeley (USA): University of California Press.

-----. 1984. The Constitution of Society. Berkeley (USA): University of California Press.

Guignon, Charles. 2004. On Being Authentic. London and New York: Routledge.

Habermas, Jürgen. 1987 [1985]. The Philosophical Discourse of Modernity. Trans. F. Lawrence. Cambridge (USA) and London: MIT Press. 
-----. 1992. Work and Weltanschauung: The Heidegger Controversy from a German Perspective. Trans. J. McCumber. In Heidegger: A Critical Reader, eds. Hubert Dreyfus and Harrison Hall, 186-208. Cambridge (USA) and Oxford: Blackwell.

Han-Pile, Béatrice. 2013. Freedom and the 'Choice to Choose Oneself' in Being and Time. In The Cambridge Companion to Heidegger's Being and Time, ed. Mark Wrathall, 291-319. Cambridge: Cambridge University Press.

Haslanger, Sally. 2012. Resisting Reality. Oxford and New York: Oxford University Press. Haugeland, John. 1982. Heidegger on Being a Person. Nôus 16: 15-26.

-----. 1992. Dasein's Disclosedness. In Heidegger: A Critical Reader, eds. Hubert Dreyfus and Harrison Hall, 81-98. Cambridge (USA) and Oxford: Blackwell.

Heidegger, Martin. 1993, 17 $7^{\text {th }}$ ed. [1927]. Sein und Zeit. Tübingen: Max Niemeyer. English editions: (1) Heidegger, M. 1962. Being and Time (trans: Macquarrie, J. and Robinson, E.). San Francisco: Harper \& Row; (2) Heidegger, M. 2010. Being and Time (trans: Stambaugh, J. and rev: Schmidt, D.). Albany (USA): State University of New York Press.

-----. 1989, $2^{\text {nd }}$ ed. [1975]. Die Grundprobleme der Phänomenologie, Gesamtausgabe: Band 24. Frankfurt/Main: Vittorio Klostermann. English edition: Heidegger, M. 1988, rev. ed. [1982]. The Basic Problems of Phenomenology (trans: Hofstadter, A.). Bloomington and Indianapolis: Indiana University Press.

Holland, Nancy, and Huntington, Patricia, eds. 2001. Feminist Interpretations of Martin Heidegger. University Park (USA): The Pennsylvania State University Press.

Käufer, Stephan. 2015. Jaspers, Limit-Situations, and the Methodological Function of Authenticity. In Heidegger, Authenticity and the Self, ed. Denis McManus, 95-115. London and New York: Routledge.

Keller, Pierre, and Weberman, David. 1998. Heidegger and the Source(s) of Intelligibility. Continental Philosophy Review 31: 369-386.

Koo, Jo-Jo. 2015. Concrete Interpersonal Encounters or Sharing a Common World: Which is More Fundamental in Phenomenological Approaches to Sociality?. In The Phenomenology of Sociality, eds. Thomas Szanto and Dermot Moran, 93-106. London and New York: Routledge.

-----. 2016. Early Heidegger on Social Reality. In The Phenomenological Approach to Social Reality, eds. Alessandro Salice and Hans Bernhard Schmid, 91-119. Cham (CH): Springer International Publishing.

Löwith, Karl. 2013 [1928]. Das Individuum in der Rolle des Mitmenschen. Freiburg/München: Karl Alber.

Magid, Oren. 2015. Further Ado concerning Dasein’s 'Undifferentiated Mode': Distinguishing the Indifferent Inauthenticity of Average Everyday Dasein from the Possibility of Genuine Failure. Journal of the British Society for Phenomenology. doi: 10.1080/00071773.2015.1021204.

McManus, Denis, ed. 2015. Heidegger, Authenticity and the Self: Themes from Division Two of Being and Time. London and New York: Routledge.

Mulhall, Stephen. 2013, $2^{\text {nd }}$ ed. [1996]. Heidegger's Being and Time. London and New York: Routledge.

Olafson, Frederick. 1987. Heidegger and the Philosophy of Mind. New Haven and London: Yale University Press.

-----. 1994a. Heidegger à la Wittgenstein or 'Coping' with Professor Dreyfus. Inquiry 37: 4564. 
----. 1994b. Individualism, Subjectivity, and Presence: A Response to Taylor Carman. Inquiry 37: 203-223.

O'Brien, Mahon. 2011. Heidegger and Authenticity. London and New York: Continuum.

----. 2014. Leaping Ahead of Heidegger: Subjectivity and Intersubjectivity in Being and Time. International Journal of Philosophical Studies 22: 534-551.

Rentsch, Thomas. 1999, $2^{\text {nd }}$ ed. [1990]. Die Konstitution der Moralität. Frankfurt/Main: Suhrkamp.

-----. 2000. Interexistentialität: Zur Transformation der existentialen Analytik Heideggers. In Negativität und praktische Vernunft, 33-45. Frankfurt/Main: Suhrkamp.

Richardson, John. 2012. Heidegger. London and New York: Routledge.

Rousse, B. Scot. 2013. Heidegger, Sociality, and Human Agency. European Journal of Philosophy. doi: 10.1111/ejop.12067.

Schatzki, Theodore. 1992. Early Heidegger on Being, the Clearing, and Realism. In Heidegger: A Critical Reader, eds. Hubert Dreyfus and Harrison Hall, 81-98. Cambridge (USA) and Oxford: Blackwell.

----. 2005. Early Heidegger on Sociality. In A Companion to Heidegger, eds. Hubert Dreyfus and Mark Wrathall, 233-47. Malden (USA) and Oxford: Blackwell.

Schmid, Hans Bernhard. 2005. Wir-Intentionalität. Freiburg/München: Karl Alber.

----. 2009. Plural Action. Dordrecht: Springer.

Stroh, Kyle M. 2015. Intersubjectivity of Dasein in Heidegger's Being and Time: How Authenticity is a Return to Community. Human Studies 38: 243-259.

Taylor, Charles. 1992. The Ethics of Authenticity. Cambridge (USA): Harvard University Press.

Theunissen, Michael. 1984 [1964]. The Other. Trans. C. Macann. Cambridge (USA) and London: MIT Press.

Wisnewski, J. Jeremy. 2013. Heidegger. Lanham (USA): Rowman \& Littlefield.

Wrathall, Mark, ed. 2013. The Cambridge Companion to Heidegger's Being and Time. Cambridge: Cambridge University Press.

Young, Iris. 1990. Justice and the Politics of Difference. Princeton: Princeton University Press. 